\title{
Glanidium botocudo, a new species from the rio Doce and rio Mucuri, Minas Gerais, Brazil (Siluriformes: Auchenipteridae) with comments on taxonomic position of Glanidium bockmanni Sarmento-Soares \& Buckup
}

\author{
Luisa Maria Sarmento-Soares ${ }^{1,2}$ and Ronaldo Fernando Martins-Pinheiro ${ }^{1}$
}

Glanidium botocudo, new species, is described from the tributaries to the upper rio Doce and Mucuri, eastern Minas Gerais State, Brazil. It represents the northernmost record of a centromochlin catfish from the coastal rivers of the Northeastern Atlantic Forest. Glanidium botocudo is readily distinguished from its congeners, except Glanidium albescens, by the whitish grey body coloration with evenly spaced small dark brown dots. The new species has a long sharpened ventral process on the urohyal, an uncommon condition among congeners, and the lowest vertebral count among the large-sized Glanidium, 36-37. It differs from Glanidium albescens by proportional measurements and higher number of ribs. Glanidium botocudo and Glanidium albescens are probably sister species, exhibiting similar morphological features and a complimentary distribution pattern, associated to an allopatric distribution pattern. Glanidium bockmanni is transferred to the genus Centromochlus.

Glanidium botocudo, espécie nova, é descrita para tributários do alto rio Doce e rio Mucuri, leste de Minas Gerais, Brasil. Representa o registro mais ao norte de um bagre centromoclíneo nos rios do Nordeste da Mata Atlântica. Glanidium botocudo é prontamente distinguido de todos seus congêneres, exceto Glanidium albescens, pelo colorido cinza-esbranquiçado do corpo com máculas castanho-escuras regularmente espaçadas. A espécie nova apresenta processo ventral do uro-hial longo e afilado, uma condição incomum entre os congêneres, e ainda a menor contagem vertebral entre os Glanidium de grande porte, 36-37. Diferencia-se de Glanidium albescens por proporções corporais e maior número de costelas. Glanidium botocudo e Glanidium albescens são possivelmente espécies irmãs, apresentando características morfológicas similares e padrões de distribuição complementar, associados a um padrão de distribuição alopátrica. Glanidium bockmanni é transferido para o gênero Centromochlus.

Key words:, Centromochlinae, Centromochlus, Distribution, South America, Systematics.

\section{Introduction}

Fishes of the auchenipterid subfamily Centromochlinae are spread throughout cis-Andean South America, and comprise the genera Centromochlus Kner, Tatia MirandaRibeiro, Glanidium Lütken, and Gelanoglanis Böhlke.

Glanidium contains seven recognized species, ranging from coastal rivers along Suriname to river systems draining the laguna dos Patos system in southern Brazil (Akama \& Sarmento-Soares, 2007; Ferraris, 2007). A single, disjunct, northern species, Glanidium leopardus Hoedeman was recorded from river basins in Suriname and French Guiana. Two species inhabit upper and middle portions of rio São Francisco drainage, Glanidium albescens Lütken and Glanidium bockmanni Sarmento-Soares \& Buckup. Two additional species, Glanidium ribeiroi Haseman and Glanidium cesarpintoi Ihering, were described from the rio Paraná system, respectively from the rio Iguaçu system and upper rio Paraná basin. In the Brazilian coastal rivers between southern Espírito Santo and Rio Grande do Sul there are two species, Glanidium melanopterum Miranda Ribeiro, described from upper rio Paraíba do Sul, and Glanidium catharinensis Miranda Ribeiro, described from a coastal Santa Catarina river basin. These two species are in need of further investigation regarding their identity and limits of distribution.

Glanidium is the sole centromochlin genus with representatives in the rio São Francisco basin and in small riverine basins along the Brazilian coast and is the only genus within the subfamily without representatives in the Amazon and Orinoco river systems. On the other hand, the remaining centromochlin members are mainly distributed in inland drainages, such as the Amazon and Orinoco. Glanidium species are found in sympatry with some Tatia species in upper portions of rio Paraná drainage. Sympatry among species from distinct centromochlin genera is also observed in other drainages, such as the Amazon.

\footnotetext{
${ }^{1}$ Museu de Biologia Prof. Mello Leitão, Av. José Ruschi, 4, Centro, 29650-000 Santa Teresa, ES, Brazil. ronaldo@nossacasa.net (RMP) ${ }^{2}$ Universidade Federal do Espírito Santo, Programa de Pós-Graduação em Biologia Animal. Av. Marechal Campos, 1468, Prédio da Biologia, Câmpus de Maruípe, 29043-900 Vitória, ES, Brazil. luisa@nossosriachos.net (LMSS)
} 
In the present paper we describe a new species of Glanidium from eastern coastal rivers of the Brazilian Floresta Atlântica. The population at rio Doce and rio Mucuri was referred to $G$. albescens in Sarmento-Soares \& Martins-Pinheiro (2007), but additional comparisons revealed it as a new species. It represents the first report of members of the subfamily in river drainages crossing the coastal tablelands relief of the Barreiras Group.

\section{Material and Methods}

Osteological features were examined in cleared and stained (CS) specimens prepared according to the procedures of Taylor $\&$ van Dyke (1985). Prior to clearing and staining, specimens were dissected whenever possible to determine gut contents, sexual maturity of gonads, and to record myological information. Osteological data from some species poorly represented in ichthyological collections were obtained from radiographs (indicated as " $\mathrm{R}$ " in the Comparative Material section). Nomenclature of osteological elements is based on Fink \& Fink (1981), Arratia (2003) and nomenclatural suggestions by Britto (2002) and Birindelli (2010). Most names are explained in The Zebrafish Information Network (ZFIN, 2012). Muscle names follow Sarmento-Soares \& Porto (2006). Drawings were rendered from a camera lucida or from digital photographs preferably of CS specimens. Straight-line measurements were made with a digital caliper, and recorded in tenths of a millimeter.

Measurements included: standard length (SL, from snout tip to caudal-fin base); body depth (on nuchal shield, from origin of dorsal-fin spine to the belly); body width (widest distance between lateral surfaces of cleithra, taken between anterior-most margin of cleithral bone beneath pectoral-fin origin); caudal-peduncle depth (least distance between dorsal and ventral surfaces of caudal peduncle); caudal-peduncle length (from base of posterior-most anal-fin ray to point coinciding with origin of lowermost principal caudal-fin ray); predorsal length (from snout tip to origin of dorsal fin); preanal length (from snout tip to anal-fin origin); prepelvic length (from snout tip to pelvic-fin origin); dorsal-fin origin to pectoral-fin origin; dorsal-fin origin to pelvic-fin origin; pectoral-fin origin to pelvic-fin origin; prepectoral length (from snout tip to pectoral-fin origin); dorsal-fin base (from origin of dorsal-fin spine to posterior-most base of dorsal-fin insertion); adiposefin base (from origin of adipose fin fold to its posterior-most base); anal-fin base (distance between genital opening and posterior-most base of anal-fin insertion, measured under the same criteria for both males and females); dorsal-fin spine length (from base of spine to its distal tip); pectoral-fin spine length (from origin of spine to its distal tip, taken with the spine erected); postcleithral (humeral) process length (from anterodorsal margin of exposed process to posterior-most tip of process); first branched pelvic-fin ray (from base to tip of first branched pelvicfin ray); longest anal-fin ray (from base to tip of first branched anal-fin ray); head length (HL, from snout tip to bony end of opercle); head width (between dorsalmost extents of opercular openings); snout depth (distance in median sagittal plane between posterior nostril and midventral contour of body); interorbital distance (least distance between dorsalmost margins of bony orbit); left internarial width (between left anterior and left posterior nostrils); anterior internarial distance (transverse distance between anterior nostrils); posterior internarial distance (transverse distance between posterior nostrils); snout length (from snout tip to anteriormost margin of eye); maxillarybarbel length (from base to tip, with barbel retracted); outer mental-barbel length (from base to tip, with barbel retracted); inner mental-barbel length (from base to tip, with barbel retracted); eye diameter (greatest horizontal diameter of eyeball); mouth width (between corners of closed mouth).

Counts of fin rays and bony elements were obtained from alcohol-preserved and CS specimens. Vertebral counts included all rib-bearing centra plus five anterior, complex centrum elements without ribs, and included the compound caudal centrum (PU1+U1) as the last element. Counts of branchiostegal rays were done only in cleared and stained specimens.

Institutional abbreviations are as follows: Departmento de Zoologia e Botânica, Universidade Estadual Paulista "Júlio de Mesquita Filho", câmpus de São José do Rio Preto, São José do Rio Preto (DZSJRP); Departamento de Zoologia, Universidade Federal de Minas Gerais, Belo Horizonte (DZUFMG); Field Musem of Natural History, Chicago (FMNH); Museu de Biologia Professor Mello Leitão, Santa Teresa (MBML); Museu de Ciências e Tecnologia, Pontifícia Universidade Católica do Rio Grande do Sul, Porto Alegre (MCP); Museu de História Natural Capão da Imbuia, Curitiba (MHNCI); Museu Nacional, Rio de Janeiro (MNRJ); Museu de Zoologia da Universidade de São Paulo, São Paulo (MZUSP); Netherlands Centre for Biodiversity Naturalis (formerly Rijksmuseum van Natuurlijke Historie), Leiden (RMNH. PISC); Núcleo de Pesquisas em Limnologia, Ictiologia e Aquicultura/ Fundação Universidade Estadual de Maringá, Maringá (NUP), National Museum of Natural History, Smithsonian Institution, Washington D.C. (USNM) and Zoologisk Museum, Copenhagen (ZMUC).

\section{Results}

Comments on Glanidium bockmanni. Glanidium is recognized as a monophyletic clade and regarded as the sister group to other centromochlin genera (Soares-Porto, 1998; Birindelli, 2010). We observed that the small-sized G. bockmanni, is remarkably distinct from the large-sized Glanidium species. Glanidium is the only Centromochlin genus with species exhibiting a large number of segments on the third modified unbranched anal-fin ray of adult males (26-43 segments). However, G. bockmanni male anal fin bears 13-15 segments on third unbranched anal-fin ray (Sarmento-Soares \& Buckup, 2005). The proximal anal-fin radials becoming enlarged and sutured to each other in mature males is a uniquely derived feature of Glanidium (Soares-Porto, 1998: fig. 19). In comparison to the sutured proximal radials in males of other Glanidium species, G. bockmanni exhibits a partial fusion of proximal radials in the anal fin of modified adult males (illustrated in Sarmento- Soares \& Buckup, 2005: fig. 3). Birindelli (2010: 287) noticed such a fusion and postulated the need of further investigations regarding Glanidium monophyly. 
Glanidium bockmanni exhibits other features not found in the remaining Glanidium species, such as: the absence of the first nuchal plate (vs. presence), the thin $\mathrm{m}$. adductor mandibulae muscle section A2, associated to a discrete concavity between the sphenotic and the pterotic ( $v s$. voluminous A2, associated to deep concavity), and the proportionally larger eye diameter, 20 $24 \%$ of HL (vs. $14-22 \%$ of HL). Glanidium bockmanni belongs to the clade composed by Centromochlus, Tatia, and Gelanoglanis, given that all its proximal radials are basally fused to each other, forming a single ossification (character 30 - state 2 of Soares-Porto, 1998). Glanidium bockmanni is a valid centromochlin species, but should not belong to Glanidium. According to the synapomorphies of Centromochlus hypothesized by Soares-Porto (1998), G. bockmanni bear a maxilla longer than the palatine (character 2 - state 1 of Soares-Porto, 1998: 334) and an elongate ventrolateral process of infraorbital 1 (lacrimal of Soares-Porto, 1998), forming anterior border of orbit (character 14 - state 1 of Soares-Porto, 1998: 338). Centromochlus monophyly requires further investigation, but on its present arrangement, G. bockmanni presents the derived features postulated for that genus. Therefore, we herein propose the transfer of the species to the genus Centromochlus, i.e., Centromochlus bockmanni, new combination.

\section{Glanidium botocudo, new species}

Fig. 1

Holotype. MNRJ 32538, 93.0 mm SL, Brazil, Minas Gerais State, Nanuque, rio Mucuri, downstream from Santa Clara Dam, approximately $17^{\circ} 53$ '28'’S $40^{\circ} 12^{\prime} 58^{\prime}$ 'W, Nov 1997 , P. S. Pompeu \& A. L. Godinho.

Paratypes. All from Brazil, Minas Gerais. DZUFMG 47, 1, $95.0 \mathrm{~mm}$ SL, collected with the holotype. DZUFMG 48, 1, 83.0 mm SL and MNRJ 32539, 1, CS, $82.0 \mathrm{~mm}$ SL, Ponte Nova, rio Doce basin, rio Piranga, on area of influence of Baú I Dam, $20^{\circ} 17^{\prime} 07^{\prime}$ 'S 42 $55^{\prime}$ '13”W, Mar 1998, F. Vieira \& P. S. Pompeu. DZUFMG 49, 1, 89.0 mm SL, limit between Dores de Guanhães and Braúnas, rio Doce basin, rio Santo Antônio drainage, rio Guanhães at Salto Grande Reservoir, 1906'17'S 42 $47^{\circ} 13^{\prime \prime} \mathrm{W}$, Jan 1999, F. Vieira \& P. S. Pompeu. MBML 2047, 2, R, 86.8$95.5 \mathrm{~mm}$ SL, Santa Cruz do Escalvado, rio Doce on area of influence of Baú I Dam, 20¹5'24”S 4254'56”W, Mar 1998, F. Vieira \& P. S. Pompeu. MNRJ 31460, 2, 83.0-91.0 mm SL, córrego Joanésia, tributary of rio Santo Antônio, Joanésia, near limits with Açucena, downstream from Porto Estrela Reservoir, rio Doce basin, 1907'48.6”S 42³9'21.2”W, 2-6 Dec 2004, R. E. S. Hojo.

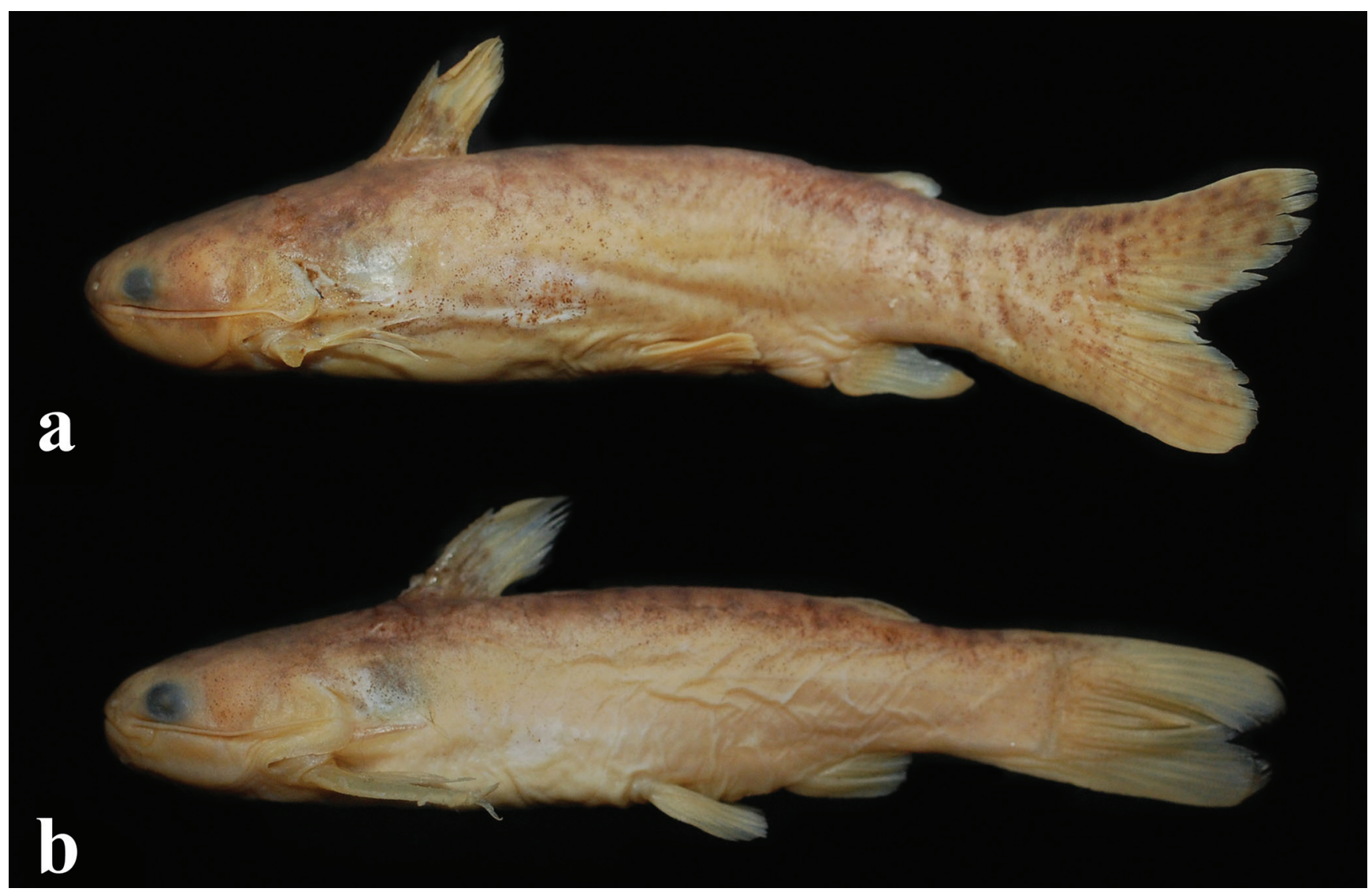

Fig. 1. Glanidium botocudo, new species, (a) holotype, MNRJ 32538, male, $93.2 \mathrm{~mm}$ SL, rio Mucuri downstream from Santa Clara Dam, Nanuque, Minas Gerais State, Brazil. (b) paratype, MBML 2047, female, 86.8 mm SL, rio Doce, on area of influence of Baú I Dam, Santa Cruz do Escalvado, Minas Gerais State, Brazil. 
Diagnosis. Glanidium botocudo is distinguished from its congeners, except $G$. albescens, by having small dark spots over a pale yellow ground color ( $v s$. large dark blotches over a pale brown ground color). The new species differs from $G$. albescens by proportions of pectoral fin spine length, about $21-26 \%$ in SL (vs. $17-20 \%$ in SL), by rib count 10 (vs. 9) and vertebral count 36-37 (vs. 38-39). Glanidium botocudo is distinguished from G. cesarpintoi, G. albescens, G. leopardum, G. melanopterum, G. catharinensis, and G. ribeiroi by having 36 or $37(\mathrm{n}=5)$ vertebrae (vs. 38 or 39 in G. cesarpintoi $(\mathrm{n}=2)$, 38 or 39 in G. albescens $(\mathrm{n}=3), 40$ or 41 in G. leopardum $(\mathrm{n}=$ 2), 41 in G. melanopterum ( $\mathrm{n}=5), 41$ in G. catharinensis ( $\mathrm{n}=$ $2)$, and 44 in G. ribeiroi $(\mathrm{n}=2)$. The new species is also distinguished by having the anterior margin of the pectoralfin spine with serrae on its entire margin ( $v s$. serrae restricted to distal portion of spine in G. melanopterum, G. catharinensis and G. ribeiroi or smooth anterior margin in G. leopardum) and by a long sharpened ventral process on urohyal (vs. distinctly short robust process in G. melanopterum, $G$. cesarpintoi, G. catharinensis, and G. ribeiroi).
Description. Morphometric data in Table 1. Body short, head slightly depressed dorso-ventrally. Head robust, outline of head in dorsal view somewhat elliptic, longer than broad. Trunk from dorsal-fin base to caudal peduncle gradually compressed. Lateral profile of head from snout tip to opercular margin slightly convex until pectoral-fin insertion. Ventral profile of head and abdomen almost straight. Ventral profile of body gently curved, concave behind anal-fin origin. Head integument thick, cranial roof not visible; well-developed adipose eye lid; eye latero-dorsally located in anterior portion of head; mouth terminal, upper lip extended postero-laterally as well-developed fleshy rictal fold; snout margin rounded, in dorsal view; anterior nostril tubular, located on anterior border of snout; posterior nostril somewhat larger, rounded, limited by small skin flap; transverse distance between anterior nostrils proportionally shorter than distance between posterior ones. Maxillary barbel short, extending slightly beyond membranous border of opercle, reaching posterior cleithral process base; mental barbels short, tip not reaching pectoral-fin base, arranged in arc along ventral surface of

Table 1. Morphometric data for Glanidium botocudo. $\mathrm{SD}=$ standard deviation; $\mathrm{N}=$ number of specimens examined.

\begin{tabular}{|c|c|c|c|c|c|}
\hline & Holotype & Range & Mean & $\mathrm{SD}$ & $\mathrm{N}$ \\
\hline Standard length $(\mathrm{mm})$ & 93.2 & $82.0-95.5$ & 88.6 & & 9 \\
\hline \multicolumn{6}{|c|}{ Percents of standard length } \\
\hline Body depth & 19.6 & $16.5-22.1$ & 20.2 & 1.60 & 9 \\
\hline Body width & 20.8 & $20.8-22.5$ & 21.8 & 0.63 & 9 \\
\hline Caudal-peduncle depth & 11.4 & $10.4-12.7$ & 11.3 & 0.78 & 9 \\
\hline Caudal-peduncle length & 25.5 & $20.4-25.5$ & 22.0 & 1.77 & 9 \\
\hline Predorsal length & 32.4 & $32.4-35.6$ & 34.5 & 1.08 & 9 \\
\hline Preanal length male & 74.0 & 73.3-76.3 & 74.6 & 1.59 & 4 \\
\hline Preanal length female & - & $68.6-72.1$ & 69.3 & 1.55 & 5 \\
\hline Prepelvic length & 54.3 & $52.8-58.4$ & 55.5 & 1.62 & 9 \\
\hline Dorsal-fin origin to pectoral-fin origin & 20.9 & $20.9-25.1$ & 22.9 & 1.42 & 9 \\
\hline Dorsal-fin origin to pelvic-fin origin & 31.2 & 29.4-34.0 & 31.7 & 1.30 & 9 \\
\hline Pectoral-fin origin to pelvic-fin origin & 36.8 & 32.9-37.4 & 35.6 & 1.72 & 9 \\
\hline Prepectoral length & 22.2 & $22.2-25.7$ & 23.7 & 1.56 & 9 \\
\hline Dorsal-fin base length & 10.2 & $7.9-10.9$ & 9.4 & 1.12 & 9 \\
\hline Adipose-fin base length & 5.0 & $3.4-5.4$ & 4.3 & 0.70 & 9 \\
\hline Anal-fin base length male & 6.7 & $5.7-6.7$ & 6.0 & 0.52 & 4 \\
\hline Anal-fin base length female & - & $9.5-11.0$ & 10.0 & 0.58 & 5 \\
\hline Dorsal-fin spine length & 13.0 & $13.0-17.2$ & 14.9 & 1.78 & 9 \\
\hline Pectoral-fin spine length & - & $20.7-26.0$ & 22.9 & 1.69 & 7 \\
\hline Length of posterior process of cleithrum & 13.7 & 13.7-18.9 & 16.6 & 1.47 & 9 \\
\hline Length of first branched pelvic-fin ray & 13.7 & $12.1-14.0$ & 12.8 & 0.71 & 9 \\
\hline Longest anal-fin ray of males & 14.8 & $13.9-15.0$ & 14.6 & 0.57 & 4 \\
\hline Longest anal-fin ray of females & - & $12.2-13.7$ & 12.7 & 0.58 & 5 \\
\hline Maxillary barbel length & 26.6 & $26.2-32.3$ & 28.6 & 2.06 & 9 \\
\hline Outer mental barbel length & 8.3 & 7.3-9.3 & 8.3 & 0.61 & 9 \\
\hline Inner mental barbel length & 4.9 & $4.6-6.2$ & 5.3 & 0.53 & 9 \\
\hline Head length & 24.0 & $24.0-26.7$ & 25.3 & 0.85 & 9 \\
\hline \multicolumn{6}{|c|}{ Percents of head length } \\
\hline Head width & 79.5 & $73.6-79.5$ & 75.7 & 1.84 & 9 \\
\hline Head depth & 46.4 & $46.4-51.2$ & 48.8 & 1.85 & 9 \\
\hline Interorbital distance & 53.1 & $48.6-53.8$ & 51.1 & 1.78 & 9 \\
\hline Left internarial width & 20.5 & $18.6-20.5$ & 19.5 & 0.60 & 9 \\
\hline Anterior Internarial distance & 39.3 & $33.6-39.3$ & 35.7 & 1.90 & 9 \\
\hline Posterior internarial distance & 40.2 & $35.1-40.2$ & 37.3 & 1.98 & 9 \\
\hline Snout length & 38.4 & 33.3-38.4 & 35.5 & 1.95 & 9 \\
\hline Orbital diameter & 17.5 & $17.5-20.2$ & 18.7 & 0.89 & 9 \\
\hline Mouth width & 57.6 & $52.2-57.6$ & 55.6 & 2.04 & 9 \\
\hline
\end{tabular}


jaw; inner mental barbel about 56.2-71.0\% length of outer mentals. Posterior process of cleithrum short almost reaching vertical through origin of dorsal fin. Caudal peduncle moderately deep, depth about $10.4-12.7 \%$ SL.

Rostral border of cranium with mesethmoid longer than broad (Fig. 2, me); premaxilla underneath with synchondral articulation; elliptical cranial fontanel, with two narrow openings: anterior one between mesethmoid and frontals and posterior one limited to frontals. Fontanel apertures separated from each other by suture beneath frontal, along orbitosphenoid. Nasal ossified, tubular, with narrow medial flanges, not sutured to mesethmoid. Autopalatine as flattened tube, oriented obliquely to longitudinal axis of body. Maxilla about half size of autopalatine. Prevomer developed, with expanded arrow-shaped lateral processes, Jaws of equal size; premaxilla and dentary narrow with four or five rows of robust conical teeth. First nuchal plate irregularly shaped, somewhat ellipsoid (Fig. 2, n1); second nuchal plate slightly concave along lateral margins (Fig. 2, n2); third nuchal plate thin, projected laterally, with prominent tip (Fig. 2, n3). Epioccipital process very small (Fig. 2, pe).

Hyomandibula broad, projected anteriorly (Fig. 3, hy), connected to both quadrate and metapterygoid through cartilage and deep dentate suture. Metapterygoid conical, aswide lamina (Fig. 3, mt), joined to quadrate via dentate suture. Quadrate trapezoidal, with broad base (Fig. 3, qu), connected to preopercle, hyomandibula and metapterygoid; long preopercle (Fig. 3, po) ventral margins sutured to both quadrate and hyomandibula; suprapreopercle present as short canal bone (Fig. 3, sp); opercle laminate, ornamented and broadly subtriangular (Fig. 3, op).

Hyoid arch with urohyal reduced with long sharpened ventral process (Fig. 4, up); short dorsal hypohyal (Fig. 4, dh) associated with comparatively large ventral hypohyal (Fig. 4, vh); anterior ceratohyal well developed (Fig. 4, ac), posterior ceratohyal smaller (Fig. 4, pc); branchiostegal ray articulated to ceratohyals; branchiostegal rays 6; 4 on anterior ceratohyal, 1 associated with interceratohyal cartilage and posteriormost flattened, associated to posterior ceratohyal.

Branchial (gill) arches with urohyal, anterior to basibranchial 2; basibranchial 2 forming osseous rod, broadest anteriorly; basibranchial 3 shorter; basibranchial 4 large, flattened and cartilaginous; basibranchial 2 bordered laterally by cartilaginous head of hypobranchial 1; basibranchial 3 between cartilaginous head of hypobranchial 2 and cartilaginous hypobranchial 3; basibranchial 4 bordered laterally by cartilaginous head of ceratobranchial 4 and caudally by cartilaginous head of ceratobranchial 5 . Hypobranchial 1 tubular, and hypobranchial 2 subtriangular, mostly osseous, elongate and expanded laterally, with cartilaginous lateral and medial ends; hypobranchial 3 completely cartilaginous, trapezoidal; hypobranchial 4 absent. Five ceratobranchials, mostly ossified, cartilaginous on both ends. First and second ceratobranchials supporting single row of rakers; third and fourth ceratobranchials with two rows of rakers; fifth ceratobranchial supporting single row of rakers, expanded postero-medially to support lower pharyngeal

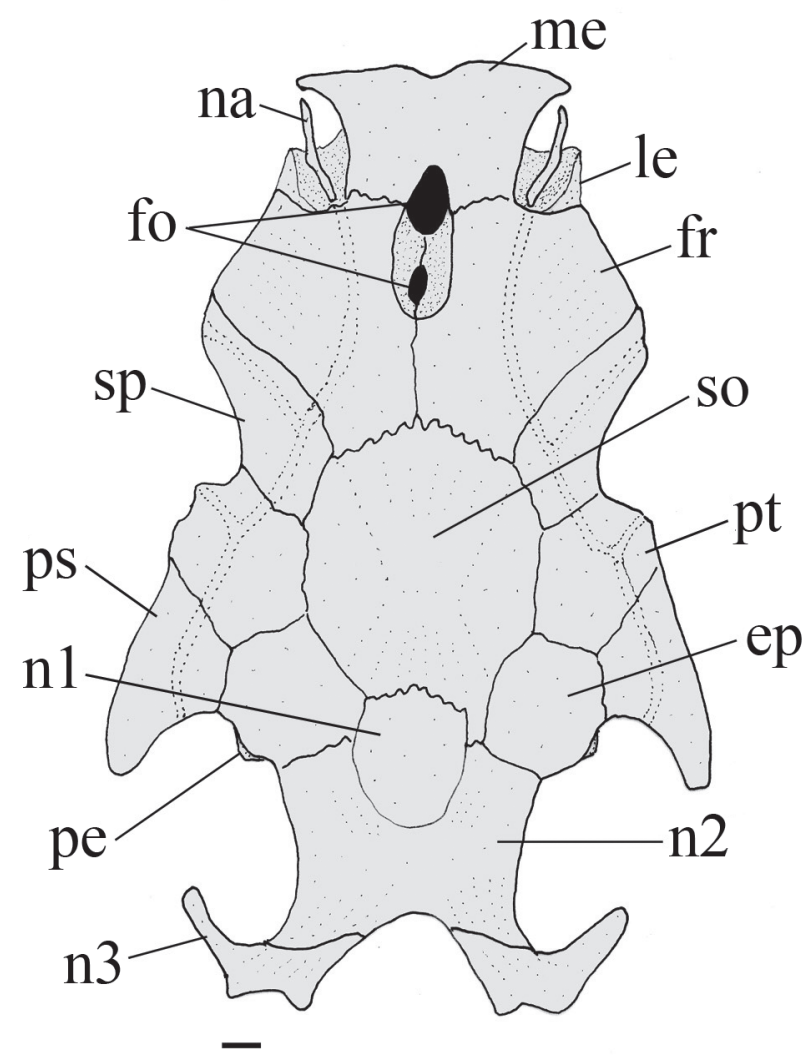

Fig. 2. Neurocranium of Glanidium botocudo, MNRJ 32539 , paratype, $82.0 \mathrm{~mm}$ SL. Dorsal view. Abbreviations: ep, epioccipital; fo, cranial fontanel, fr, frontal; le, lateral ethmoid; me, mesethmoid; na, nasal; n1, first nuchal plate, n2; second nuchal plate; $\mathrm{n} 3$, third nuchal plate; pe, posterior epioccipital process; ps, posttemporal-supracleitrum; pt, pterotic; so, supraoccipital; sp, sphenotic. Scale bar $=1.0 \mathrm{~mm}$.

toothplate with short conical teeth. Five epibranchials, all but fifth largely ossified except for cartilaginous ends, suporting one or two rakers each, close to articulation with ceratobranchials. Epibranchials 1 and 2 rod-like; epibranchial 3 with posterior uncinate process; epibranchial 4 with laminar extension; epibranchial 5 cartilaginous, reduced, located on angle between cartilaginous ends of epibranchial 4 and ceratobranchial 4. Pharyngobranchial 1 and 2 absent; accessory cartilage between anteromedial cartilaginous tips of epibranchials 1 and 2; pharyngobranchial 3 elongate, ossified, with expanded posterior border; pharyngobranchial 4 ossified. Upper pharyngeal tooth plate with conical teeth, supported by pharyngobranchial 3 and 4, and also epibranchials 3 and 4 .

Infraorbital 1 with ventro-lateral process clearly restricted to anterior border of eye. Subsequent four infraorbitals thin and tubular, in complete infraorbital series. Lateral line on body straight, inconspicuous, with ossified canal bones only anteriorly, unbranched at caudal fin. 


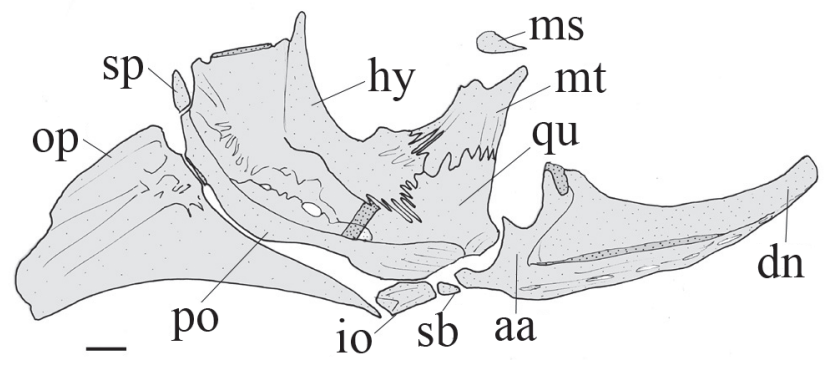

Fig. 3. Right suspensorium of Glanidium botocudo, MNRJ 32539, paratype, $82.0 \mathrm{~mm}$ SL. Lateral view. Abbreviations: aa, angulo-articular; dn, dentary; hy, hyomandibula; io, interopercle; mt, metapterygoid; ms, mesopterygoid; op, opercle; po, preopercle; qu, quadrate; sb, subpreopercle; sp, suprapreopercle. Scale bar $=1.0 \mathrm{~mm}$.

Dorsal fin II,5, dorsal-fin spine with minute serrations along entire anterior margin, posterior margin with minute serrations on distal tip only. Pectoral fin I,5, pectoral-fin spine with 1419 antrorse serrations along entire anterior margin; 13-17 retrorse serrations along posterior margin; serrations on anterior margin smaller than posterior. Pelvic-fin i,5, margin rounded. Adipose fin small, origin at vertical through anal-fin base. Anal fin iii,8; anal-fin pterygiophores in nine rod-like proximal radials and eight cartilaginous distal radials. Caudal fin deeply forked, lobes with rounded tips, $8+9$ principal rays, 16 upper procurrent, 15 lower procurrent rays.

Ribs 10 attached to consecutive vertebrae, becoming progressively smaller posteriorly. Total vertebrae 36 or 37 $(\mathrm{n}=5)$.

Color in alcohol. Dorsal surface of head, body, scattered with small dark-brown chromatophores with depigmented area around adipose fin. Ground color gradually becoming lighter towards ventral parts. Dorsal fin dark brown on its base,

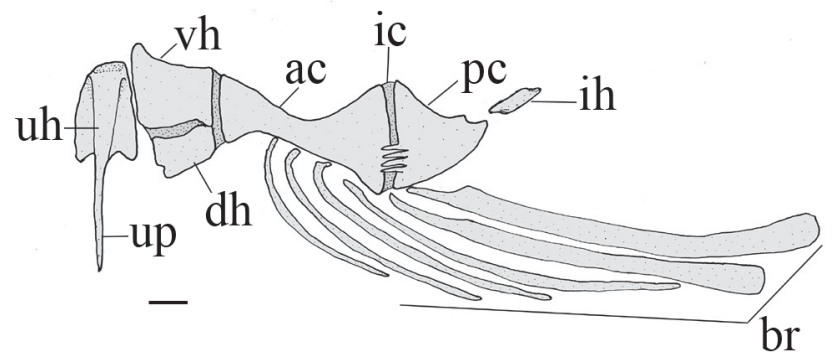

Fig. 4. Right hyoid arch of Glanidium botocudo, MNRJ 32539, paratype, $82.0 \mathrm{~mm}$ SL. Ventral view. Abbreviations: ac, anterior ceratohyal; br, branchiostegal rays; dh, dorsal hypohyal; ic, interceratohyal cartilage; ih, interhyal; pc, posterior ceratohyal; vh, ventral hypohyal; uh, urohyal; up, urohyal ventral process. Scale bar $=1.0 \mathrm{~mm}$. becoming pale yellow towards tip. Paired, anal and adipose fins unpigmented. Caudal-fin rays with small dark brown spots.

Sexual dimorphism. Female specimens with a small intumescent genital papilla; with genital and urinary apertures separate. The male genital papilla is formed by a thick skin flap around a short emergent deferent duct. Male anal fin is strongly modified, with a pointed tip formed by the enlarged and thickened third unbranched and first branched rays. First unbranched anal-fin ray proportionally short, relative to subsequent fin-rays (Fig. 5 , ui). The second unbranched anal-fin ray of males is elongated and intermediate in size between first and third anal-fin rays (Fig. 5, uii). The third unbranched anal-fin ray of males is about twice the length of first unbranched ray (Fig. 5, uiii). The male third unbranched anal-fin ray has a larger number of segments (26-29) relative to females (17-19). Posterior branched anal-fin rays of males are progressively shorter with last ray being the smallest (Fig. 5, b8).

Distribution. Glanidium botocudo was recorded from large coastal river systems, such as the rios Doce and Mucuri (Fig. 6). It is the first record of the genus for the Eastern Atlantic river system (sensu CNRH, 2003) and also for Coastal Tablelands of the Barreiras Group. Coastal tablelands correspond to a region of mild relief, with elevations usually not passing $150 \mathrm{~m}$, coinciding with the Cenozoic sediments of the Barreiras Group, well seen along the border between Espírito Santo and southern Bahia. Regarding global biogeographic regionalization of freshwater systems, the new species distribution pattern belongs to Northeastern Mata Atlantica ecoregion (sensu Abell et al., 2008).

Ecological notes. Glanidium species are nocturnal catfishes that inhabit lotic sections of rivers, and also lakes, in segments with riparian vegetation (F. Vieira, pers. comm.). Glanidium botocudo feeds on allochthonous resources, as beetles, and autochthonous aquatic invertebrates, such as insect larvae and gastropods, as evidenced by the examination of gut contents (MNRJ 32539, $82.0 \mathrm{~mm} \mathrm{SL}$ ).

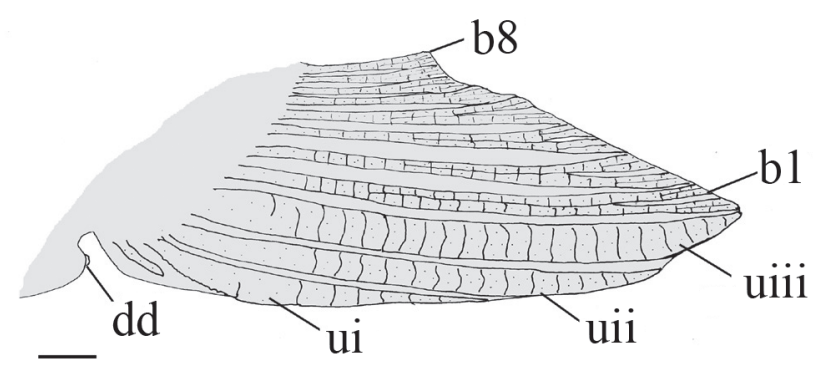

Fig. 5. Male modified anal fin of Glanidium botocudo, MNRJ 32539, paratype, $82.0 \mathrm{~mm}$ SL. Left side lateral view. Abbreviations: b1, branched first ray; b8, branched eighth ray; dd, deferent duct; ui, unbranched first ray; uii, unbranched second ray; uiii, unbranched third ray. Scale bar $=1.0 \mathrm{~mm}$. 
Etymology. The specific name is a reference to the Botocudo, the generic name given to native indigenous people wearing artifacts ("botoques") on ears and lips. Those Indians were the original inhabitants of large extensions of the Floresta Atlântica (Paraíso, 1992), including the lands along the rio Mucuri valley and far west, to the rio Doce, range of the new Glanidium species. A noun in apposition.

\section{Discussion}

Glanidium is the sister genus to remaining genera of the Centromochlinae, and retains a plesiomorphic arrangement of anal-fin rays in mature males (Soares-Porto, 1998). Although the phylogenetic position of Glanidium is well established, the monophyly of the genus deserves further investigation (see Comments on Centromochlus bockmanni).

One distinguishing feature of G. botocudo is the long sharpened ventral process on urohyal, projecting beyond the
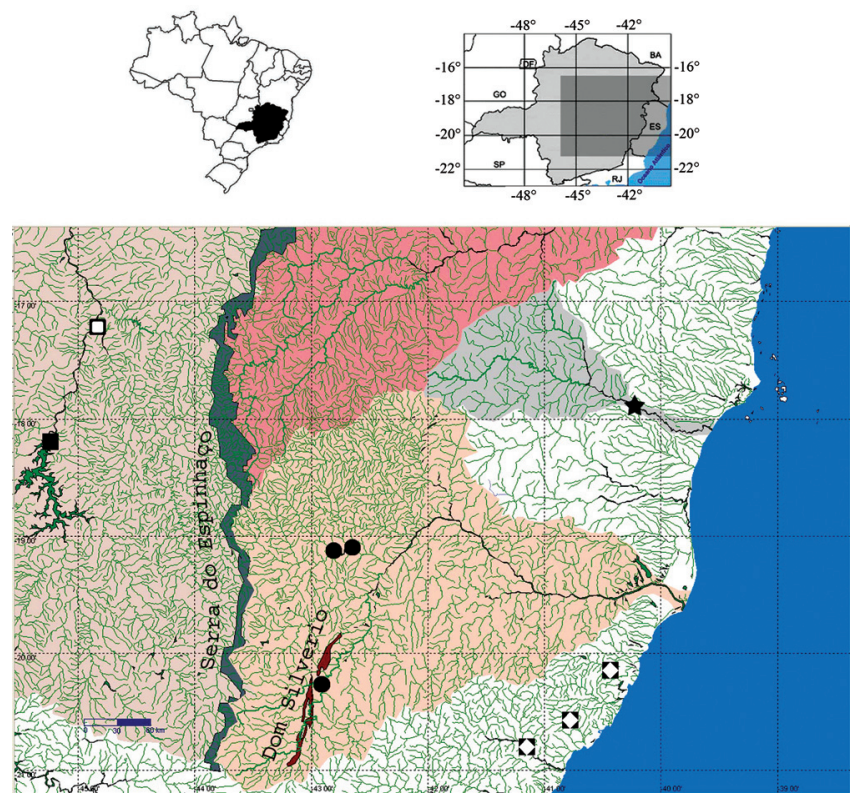

Fig. 6. Map of eastern Brazilian drainages at northeastern Minas Gerais State illustrating regional uplifts: the Serra do Espinhaço (colored in dark gray) and Dom Silvério Group (colored in brown). Contour of river basins in the area as stated: rio São Francisco (in pink), rio Jequitinhonha (in rose), rio Mucuri (in light gray), rio Doce (in salmon). Collecting localities of Glanidium botocudo illustrated as black circles. Star indicates type locality. Regional centromochlin species at rio São Francisco basin are illustrated by squares (white - Glanidium albescens; black - Centromochlus bockmanni). Congener at southern coastal rivers of Espírito Santo, Glanidium melanopterum, is illustrated by white lozenges. Symbols may represent more than one locality. Limits of Serra do Espinhaço are based on Valadão (2009) and Dom Silvério Group based on Peres et al. (2004). hypohyals, a condition not yet observed in other congeners. In centromochlin catfishes, such as Tatia, the urohyal is usually narrow with a sharp ventral process limited between hypohyals (Sarmento-Soares \& Martins-Pinheiro, 2008: fig. 4). Ferraris (1988), Walsh (1990), and Birindelli (2010) referred to a distinctively long laminar projection of urohyal in Tetranematichthys and Ageneiosus species. Such a condition in a single Glanidium species deserves further comparative investigation.

In its present arrangement, the Glanidium species are distributed in inland drainages, such as the upper portions of rio Paraná basin and also in coastal rivers systems, from the Surinam to Rio Grande do Sul, in southern Brazil. Together with G. melanopterum and G. catharinensis, G. botocudo occurs in the coastal rivers of the Brazilian Floresta Atlântica. The range of G. botocudo represents the northernmost record of the genus in the biome Floresta Atlântica.

The geographically closest congeners to G. botocudo are $G$. albescens and G. melanopterum. Glanidium melanopterum was recently recorded from coastal rivers of Espírito Santo, such as the rivers Santa Maria da Vitória, Benevente, and Itapemirim. That area corresponds to Northeastern Mata Atlântica freshwater ecoregion (sensu Abell et al., 2008) with records of both $G$. melanopterum and G. botocudo. A comparison between $G$. botocudo and G. melanopterum revealed differences, regarding general body coloration, pectoral-fin spine denticulation, proportional measurements and vertebral count.

On the other hand, G. albescens, from upper rio São Francisco and the new G. botocudo, from Floresta Atlântica river drainages of rio Doce and rio Mucuri, share a similar color pattern. Although inhabiting distinct freshwater ecoregions, São Francisco and Northeastern Mata Atlântica respectively, these two forms were first recognized as a single species. Both were named as "Pacu branco", because of the whitish grey body coloration (SarmentoSoares \& Martins-Pinheiro, 2007). Glanidium albescens and $G$. botocudo are probably sister species, exhibiting similar morphological features and a complimentary distribution pattern, associated to an allopatric distribution pattern.

The geographic range of most freshwater species is tightly linked to the course of ancient and modern river ways and watersheds (Lundberg et al., 2000). Tectonic deformations and erosive action over long time frames are expected to have subdivided and isolated fish populations, resulting in speciation, adaptation, extinction or even dispersion (Albert \& Reis, 2011). Climatic fluctuations during Quaternary are mentioned as an explanatory model regarding wide range distribution between freshwater species along Brazilian coastal rivers (e.g., Weitzman et al., 1988; Ribeiro et al., 2006; Buckup, 2011). According to this model, continental platform was exposed during several marine regressive events when the sea level was lower and rivers extended onto the continental margin. A hypothesis of stream-capture event and subsequent dispersal to explain distributional patterns in the eastern margin of the Atlantic border of the Brazilian Shield is suggested by Ribeiro (2007), exemplified by Oligosarcus acutirostris Menezes, a characid species ranging between the rio Itapemirim, in southern Espírito Santo, to extreme southern 
Bahia drainages. In Glanidium a species disjunction is observed in the same area: G. melanopterum northern records correspond to the rio Santa Maria da Vitória, on southern Espírito Santo, while $G$. botocudo inhabits the rio Doce and extreme southern Bahia rivers. A possible explanation for G. melanopterum distribution pattern through coastal river drainages until southern Espírito Santo could be active dispersal. It is possible that southnorth or northeast-southwest fault lineaments were utilized by evolving large rivers during Quaternary. Such a communication between watersheds may represent a pervasive cause of fish dispersal along the southeastern Atlantic rivers ( $c f$. Ribeiro, 2007; Buckup, 2011). This faunal dispersal could explain the distribution patterns of G. melanopterum, and also of some coastal freshwater fishes, such as Microglanis parahybae (Steindachner); Gymnotus pantherinus (Steindachner) and Australoheros muriae Ottoni \& Costa, in which northern range include Espírito Santo, south of the rio Doce.

Regarding Glanidium albescens and G. botocudo distributional patterns, the evolution of large ancient watersheds may have contributed to vicariant events. The Araçuaí Belt, first portrayed by Almeida (1977), developed along the southeastern margin of the São Francisco Craton, is one of the oldest events to influence the relief before the westernGondwana break-up (Campos-Neto \& Figueiredo, 1995; Alkmim et al., 2007). The driven forces for the closure of an inland sea, the Adamastor Ocean, are probably triggered by collisions along the margins of the São Francisco-Congo plate involving several orogenic steps during Cambro-Ordovician limit (Potter, 1997; Alkmin et al., 2007). The tectonic evolution of the southern Araçuaí belt, at southern Serra do Espinhaço, exhibited additional deformation phases during the Paleoproterozoic (Peres et al., 2004). One of these uplifts, the Dom Silvério Group, molded the hydrographic basins, by abrupt inflection of upper rio Doce channel (Fig. 6; Peres et al., 2004; Valadão, 2009: fig. 12). The final phase reflects the collapse of the Araçuaí-West Congo orogeny, with estimated ages around 509-480 Ma (Peres et al., 2004). A great escarpment, the Serra do Espinhaço (Fig. 6), emerged as a reference to the orogeny, separating the inland area, the São Francisco, from the coastal Atlantic basins, such as Paraguaçu, Contas, Pardo, Jequitinhonha, Mucuri, and Doce river drainages (Valadão, 2009). This scenario is of importance to the understanding of distributional patterns of freshwater fishes, as in Aptian, during Cretaceous fragmentation, these hydrographic coastal basins articulated to the incipient Atlantic Ocean. Many fish lineages originated by that time, including the Ostariophysi (Lundberg, 1993; Albert \& Reis, 2011).

The Serra do Espinhaço is nowadays an important watershed divide, between the São Francisco and coastal river drainages. Apparently, the Serra do Espinhaço represents an important geographical barrier to freshwater fish, as many components of the aquatic fauna are distinct between inland and coastal watersheds, as pointed out by Sarmento-Soares et al. (2008; 2009). Divergent allopatric speciation may be the case, between G. albescens, from inland São Francisco, and G. botocudo, from coastal rivers Doce and Mucuri. The allopatric pattern of geographic distributions between these two species fits into a model of long-term isolation between coastal Atlantic and São Francisco drainages.

Cenozoic geological events influenced many elements of the Neotropical biota (Albert \& Reis, 2011), and may explain the distributional patterns of Glanidium botocudo. The break-up of the Gondwana and opening of the South Atlantic Ocean has increased rates of continental denudation. In the case of inland São Francisco drainage, denudation rates were reduced, and waters passed to flow isolated, incased in a tectonic depression, by middle-upper Cretaceous (Potter, 1997; Valadão, 2009). On the other hand, the drainage basins facing the Atlantic Ocean, such as the rivers Doce, Mucuri and Jequitinhonha, experienced episodes of accelerated erosional relief processes during MesoCenozoic (Valadão, 2009). These denudation rates continued during Cenozoic and clearly influenced the northeastern Minas Gerais relief, at eastern flank of the Serra do Espinhaço (Ferraz et al., 2010). The dissected relief resulted in deep incisions in the river drainage network, coincident with the area where $G$. botocudo occurs. Anomalies observed in watershed divides between Mucuri, Doce and Jequitinhonha headwaters suggest denudation by aggressive water flow, with subsequent communication between rivers Doce and Mucuri (Ferraz et al., 2010). These elaborations drew out until Mio-Pliocene, when subsequent uplifts locked the river drainage communication. During post-Pliocene the large river valleys delineated, as Doce, Mucuri and Jequitinhonha as observed nowadays. The distribution pattern of G. botocudo may be explained by dispersal event during long time communication between Doce and Mucuri valleys until the Pliocene. Other non-closely related Ostariophysan species have distributional congruence with Glanidium botocudo, with records in both rio Doce and rio Mucuri: Pogonopoma wertheimeri (Steindachner) (Quevedo \& Reis, 2002) and Henochilus wheatlandii Garman (Castro et al., 2004), hypothesizing dispersal events between rio Doce and rio Mucuri headwaters during the Cenozoic.

This is not the only way to explain disjunct distributional patterns among inland São Francisco and coastal rivers at northern Espírito Santo to southern Bahia. Watershed capture from São Francisco to rio Doce and subsequent dispersal to rio Mucuri, could give an alternative hypothesis, but it is not clear which processes may be involved in such a stream-capture event. The complex history of eastern Atlantic rivers and its inhabitants is a challenge in understanding the cladogenetic events that took place in the area during a long time.

Comparative Material. Centromochlus bockmanni. Brazil. Rio São Francisco basin. Bahia State. MZUSP 82351, 8, 1 CS, 29.4$35.8 \mathrm{~mm}$ SL, rio Preto, Formosa do Rio Preto. Minas Gerais State. MNRJ 25798, 1, $27.5 \mathrm{~mm}$ SL, rio Jequitaí at Jequitaí, close to Francisco Dumont. MZUSP 82803, 1 R, 48.0 mm SL, holotype; MZUSP 36976, 1 R, 37.2 mm SL, paratype and MZUSP 82804, 1 CS, $41.4 \mathrm{~mm}$ SL, paratype, rio São Francisco, downstream from Três Marias Dam. Glanidium albescens. Brazil. Rio São Francisco basin. Minas Gerais State. MNRJ 16262, 4, 107.5-121.5 mm SL, rio Paraopeba, ZMUC 335, 1 R, 101.0 mm SL, syntype; ZMUC 336, 1 R, 94.0 mm SL, syntype; and ZMUC 337, 1 R, 93.0 mm SL, syntype, rio das Velhas. Glanidium catharinensis. Brazil. Paraná 
State. Rio Guaraqueçaba basin. MHNCI 6569, 2 107.2-158.0 mm SL, rio Morato. Santa Catarina State. Rio Tubarão basin. MCP 25588, 3, 116.5-138,3 mm SL, rio Capivari, tributary of rio Tubarão, Tubarão. MNRJ 5169, 1 R, 89 mm SL, holotype, rio Braço Norte, São Ludgero, Tubarão. São Paulo State. Rio Ribeira de Iguape basin. MZUSP 9308, 1 CS, rio Ribeira de Iguape, Iporanga. Glanidium cesarpintoi. Brazil. Rio Paranaíba basin. Goiás State, MNRJ uncatalogued, 3, 1 CS, 65.2-83.2 mm SL, and NUP 5699, 7, 77.7$87.9 \mathrm{~mm}$ SL, rio Corumbá (Areia), tributary of rio Paranaíba, Pires do Rio near boundary with Ipameri. Rio Tietê basin. São Paulo State. DZSJRP 4570, 1 R, 89.7 mm SL, Salto Grande Reservoir, downstream. DZSJRP 6343, 1, 13.6 mm SL, rio Borá, between Nova Aliança and Potirendaba. Glanidium leopardum. Suriname. Marowijne rivier basin. RMNH. PISC 28573, 2, 1 R, 56.0 and 71.0 mm SL; and RMNH.PISC 28576, 3, 1 CS, 37.5-71.2 mm SL, Balaté rivier. Glanidium melanopterum. Brazil. Espírito Santo State. MBML 2118, 2 R, 125.2-144.6 mm SL, rio Santa Maria da Vitória in Mangaraí, Santa Leopoldina, Rio Santa Maria da Vitória basin. MBML 2566, 2, 136.8-154.0 mm SL, and MBML 2571, 1, 153.8 $\mathrm{mm}$ SL, rio Benevente downstream Alfredo Chaves, Rio Benevente basin. MBML 3913, 1, $131.9 \mathrm{~mm}$ SL, rio Itapemirim downstream from ribeirão Itaóca, Rio Itapemirim basin. Rio de Janeiro State. Rio São João basin. MNRJ 12137, 2 R, 107.0-134.5 mm SL, lagoa de Juturnaíba, between Araruama and Silva Jardim. Rio Paraíba do Sul basin. MNRJ 12359, 1 CS, rio Paraíba do Sul, Três Rios. MNRJ 17485, 2, 129.0-190.0 mm SL, ribeirão das Lajes. USNM 41506, 1, 98.6 mm SL, rio Paraíba. Glanidium ribeiroi. Brazil. Paraná State. Rio Iguaçu basin. FMNH 54243, 1. 134.4 mm SL, holotype, Porto União da Vitória. MZUSP 45044, 4 (1 R, 1 CS), rio Iguaçu upstream Salto Santiago Dam, Laranjeiras do Sul. NUP 5698, 4, 172.0-193.0 mm SL, rio Iguaçu, downstream Caxias Reservoir, Capitão Leônidas Marques.

\section{Acknowledgments}

We thank Fabio Vieira and Marcelo F. G. de Brito for availability of specimens and collecting localities information. We are grateful to Gustavo W. Nunan (in memorian), Marcelo R. Britto and Paulo A. Buckup for their hospitality at MNRJ. For loans, exchange of specimens and/or courtesies extended during visits to their institutions we thank Francisco Langeani (DZSJRP), Mark Westneat (FMNH), Zilda Margarete Lucena, Roberto E. Reis (MCP), Vinicius Abilhoa (MHNCI), Heraldo A. Britski, Osvaldo T. Oyakawa (MZUSP), Paulo A. Buckup, Marcelo R. Britto (MNRJ), Carla S. Pavanelli (NUP), Martien J. P. van Oijen (RMNH. PISC), Sandra Raredon, Richard P. Vari (USNM) and Jorgen Nielsen (ZMUC). For radiographs and/or information about species we are indebted to Abércio A. Pereira, Érica P. Caramaschi, Fábio Vieira, James C. Coelho, Marcelo F. G. de Brito, René E. S. Hojo, Rogério L. Teixeira, and Sandra Raredon. We are grateful to the image bank of the All Catfish Species Inventory webpage. LMSS held a position as visiting researcher at MNRJ/ UFRJ, which provided partial financial support during the beginning of the present study. The senior author received financial support from the Fundação de Amparo à Pesquisa do Espírito Santo (FAPES) during the final phase of this study. The paper benefited from the comments and suggestions of José Luís O. Birindelli, John G. Lundberg and anonymous reviewers.

\section{Literature Cited}

Abell, R., M. L. Thieme, C. Revenga, M. Bryer, M. Kottelat, N. Bogutskaya, B. Coad, N. Mandrak, S. C. Balderas, W. Bussing, M. L. J. Stiassny, P. Skelton, G. R. Allen, P. Unmack, A. Naseka, R. Ng, N. Sindorf, J. Robertson, E. Armijo, J. V. Higgins, T. J. Heibel, E. Wikramanayake, D. Olson, H. L. López, R. E. Reis, J. G. Lundberg, M. H. Sabaj Pérez \& P. Petry. 2008. Freshwater ecoregions of the world: a new map of biogeographic units for freshwater biodiversity conservation. BioScience, 58: 403-414.

Akama, A. \& L. M. Sarmento-Soares. 2007. Família Auchenipteridae. Pp. 116-120. In: Buckup, P. A., N. A. Menezes \& M. S. Ghazzi (Eds.). Catálogo das espécies de peixes de água doce do Brasil. Série livros 23. Rio de Janeiro, Museu Nacional.

Albert, J. E. \& R. E. Reis. 2011. Introduction to Neotropical freshwaters. Pp. 3-19. In: Albert, J. E. \& R. E. Reis (Eds.). Historical Biogeography of Neotropical Freshwater Fishes. Berkeley, University of California Press.

Alkmim, F. F., A. C. Pedrosa-Soares, C. M. Noce \& S. C. P. Cruz. 2007. Sobre a evolução tectônica do orógeno Araçuaí-Congo Ocidental. Geonomos, 15: 25-43.

Almeida, F. F. M. 1977. O cráton do São Francisco. Revista Brasileira de Geociências, 7: 285-295.

Arratia, G. 2003. Catfish head skeleton. An overview. Pp. 20-46. In: Arratia, G., B. G. Kapoor, M. Chardon \& R. Diogo (Eds.). Catfishes. Enfield, Science Publishers.

Birindelli, J. L. O. 2010. Relações filogenéticas da superfamília Doradoidea (Ostariophysi, Siluriformes). Unpublished Ph.D. Dissertation, Universidade de São Paulo, São Paulo, 387p.

Britto, M. R. 2002. Análise filogenética da ordem Siluriformes com ênfase nas relações da superfamília Loricarioidea (Teleostei: Ostariophysi). Unpublished Ph.D. Dissertation, Universidade de São Paulo, São Paulo, 512p.

Buckup, P. A. 2011. The Eastern Brazilian shield. Pp. 203-210. In: Albert, J. E. \& R. E. Reis (Eds.). Historical biogeography of Neotropical freshwater fishes. Berkeley, University of California Press.

Campos Neto, M. C. \& M. C. H. Figueiredo 1995. The Rio Doce orogeny, Southeastern Brazil. Journal of South American Earth Sciences, 8: 143-162.

Castro, R. M. C., R. P. Vari, F. Vieira \& C. Oliveira. 2004. Phylogenetic analysis and redescription of the genus Henochilus (Characiformes: Characidae). Copeia, 2004: 496-506.

CNRH - Conselho Nacional de Recursos Hídricos. 2003. Resolução no 32, 15 de outubro de 2003. Diário Oficial da União, 17 Dec /2003.

Ferraris, C. J., Jr. 1988. The Auchenipteridae: putative monophyly and systematics, with a classification of the Neotropical doradoid catfishes (Ostariophysi: Siluriformes). Unpublished Ph. D. Dissertation, City University of New York, New York, 229p.

Ferraris, C. J., Jr. 2007. Checklist of catfishes, recent and fossil (Osteichthyes: Siluriformes), and catalogue of siluriform primary types. Zootaxa, 1418: 1-628.

Ferraz, C. M. L., D. S. Parreira, D. R. Silva, B. P. Pereira Neto \& R. C. Valadão. 2010. Tectônica Cenozóica do nordeste de Minas Gerais ao sul da Bahia. Revista Multidisciplinar do Nordeste Mineiro, 1: 1-14.

Fink, S. V. \& W. L. Fink. 1981. Interrelationships of the ostariophysan fishes (Teleostei). Zoological Journal of the Linnean Society, 72: 297-353.

Haseman, J. D. 1911. Some new species of fishes from the Rio Iguassú. Annals of the Carnegie Museum, 7: 374-387. 
Hoedeman, J. J. 1961. Notes on the ichthyology of Surinam and other Guianas. 8. Additional records of siluriform fishes. Bulletin of Aquatic Biology, 2: 129-139.

Ihering, R. von. 1928. Glanidium cesarpintoi n. sp. de peixe de couro (fam. Siluridae sub-fam. Auchenipterinae). Boletim Biologico, Laboratorio de Parasitologia, Faculdade de Medicina de São Paulo, 12: 46-49.

Lundberg, J. G. 1993. African-South American freshwater fish clades and continental drift: problems with a paradigm. Pp.156-199. In: Goldblatt, P. (Ed.). Biological relationships between Africa and South America. New Haven, Yale University Press.

Lundberg, J. G., M. Kottelat, G. R. Smith, M. L. J. Stiassny \& A. C. Gill. 2000. So many fishes, so little time: An overview of recent ichthyological discovery in continental waters. Annals of the Missouri Botanical Garden, 87: 26-62.

Lütken, C. F. 1875. Velhas-Flodens Fiske. Et Bigrag til Brasiliens Ichthyologi. Elfter Professor J. Reinhardt Indsamlinger og Optegnelser. Kongelige Danske Videnskabernes Selskab Kiøbenhavske, 12: 121-253.

Miranda Ribeiro, A. 1918. Três gêneros e dezessete espécies novas de peixes brasileiros. Revista do Museu Paulista, 10: 631-646.

Miranda Ribeiro, P. 1962. Catálogo dos peixes do Museu Nacional, IX. Publicações Avulsas do Museu Nacional, Rio de Janeiro, 45: 1-12.

Paraíso, M. H. B. 1992. Os botocudos e sua trajetória histórica. Pp. 413-430. In: Cunha, M. C. (Ed.). História dos índios no Brasil. São Paulo, Companhia das Letras/ Secretaria Municipal de Cultura/ FAPESP.

Peres, G. G., F. F. Alkmim \& H. Jordt-Evangelista. 2004. The southern Araçuaí belt and the Dom Silvério Group: Geologic architecture and tectonic significance. Anais da Academia Brasileira de Ciências, 76: 771-790.

Potter, P. E. 1997. The Mesozoic and Cenozoic paleodrainage of South America: A natural history. Journal of South American Earth Sciences, 10: 331-344.

Quevedo, R. \& R. E. Reis. 2002. Pogonopoma obscurum: a new species of loricariid catfish (Siluriformes: Loricariidae) from southern Brazil, with comments on the genus Pogonopoma. Copeia, 2002: 402-410.

Ribeiro, A. C., F. C. T. Lima, C. Riccomini \& N. A. Menezes. 2006. Fishes of the Atlantic rainforest of Boracéia: testimonies of the Quaternary fault reactivation within a Neoproterozoic tectonic province in Southeastern Brazil. Ichthyological Exploration of Freshwaters, 17: 157-164.

Ribeiro, A. C. 2007. Filogenia e biogeografia do gênero Oligosarcus Günther, 1864 (Ostariophysi; Characidae). Unpublished Ph.D. Dissertation, Universidade Estadual Paulista "Júlio de Mesquita Filho", Botucatu,138p.

Sarmento-Soares, L. M. \& P. A. Buckup. 2005. A new Glanidium from the Rio São Francisco basin, Brazil (Siluriformes: Auchenipteridae: Centromochlinae). Copeia, 2005: 846-853.
Sarmento-Soares, L.M. \& R. F. Martins-Pinheiro. 2007. Os Auchenipteridae do Leste do Brasil. Boletim da Sociedade Brasileira de Ictiologia, 87: 7-8.

Sarmento-Soares, L. M. \& R. F. Martins-Pinheiro. 2008. A systematic revision of Tatia (Siluriformes: Auchenipteridae: Centromochlinae). Neotropical Ichthyology, 6: 495-542.

Sarmento-Soares, L. M., R. Mazzoni \& R. F. Martins-Pinheiro. 2008. A fauna de peixes dos Rios dos Portos Seguros, extremo Sul da Bahia, Brasil. Boletim do Museu de Biologia Mello Leitão, 24: 121-144.

Sarmento-Soares, L. M., R. Mazzoni \& R. F. Martins-Pinheiro. 2009. A fauna de peixes na bacia do Rio Jucuruçu, leste de Minas Gerais e extremo Sul da Bahia. Pan-American Journal of Aquatic Sciences, 4: 193-207.

Sarmento-Soares, L. M. \& M. Porto. 2006. Comparative anatomy of the cheek muscles within the Centromochlinae subfamily (Ostariophysi, Siluriformes, Auchenipteridae). Journal of Morphology, 267: 187-197.

Soares-Porto, L. M. 1998. Monophyly and interrelationships of the Centromochlinae (Siluriformes, Auchenipteridae). Pp. 331350. In: Malabarba, L. R., R. E. Reis, R. P. Vari, Z. M. S. Lucena \& C. A. S. Lucena (Eds.). Phylogeny and Classification of Neotropical fishes. Porto Alegre, Edipucrs.

Taylor, W. R. \& G. van Dyke, 1985. Revised procedures for staining and clearing small fishes and other vertebrates for bone and cartilage study. Cybium, 9: 107-119.

Valadão, R. C. 2009. Geodinâmica de superfícies de aplanamento, desnudação continental e tectônica ativa como condicionantes da megageomorfologia do Brasil Oriental. Revista Brasileira de Geomorfologia, 10: 77-90.

Walsh, S. J. 1990. A systematic revision of the Neotropical catfish family Ageneiosidae (Teleostei: Ostariophysi: Siluriformes). Unpublished Ph.D. Dissertation, University of Florida, Gainesville, 363p.

Weitzman, S. H., N. A. Menezes \& M. J. Weitzman. 1988. Phylogenetic biogeography of the glandulocaudini (Teleostei: Characiformes, Characidae) with comments on the distribution of other freshwater fishes in eastern and southeastern Brazil. Pp. 379-427. In: Vanzolini, P. E., \& W. R. Heyer (Eds.). Proceedings of a workshop on Neotropical distribution patterns. Rio de Janeiro, Academia Brasileira de Ciências.

ZFIN Project - Zebrafish Model Organism Database (ZFIN), Zebrafish Anatomical Ontology, University of Oregon, Eugene, OR 97403-5274. Available from: http://zfin.org/action/anatomy/ anatomy-search. (25 Aug 2012).

Submitted September 12, 2012 Accepted April 14, 2013 by Paulo Lucinda Published June 28, 2013 